\title{
BAGAIMANA POLA PERENCANAAN DAN PENGELOLAAN KEUANGAN KELUARGA MUSLIM ETNIS ARAB YANG BERPROFESI USTADZ DAN DOKTER DI SURABAYA')
}

\author{
Syelvi Salama Binti Abdullah Bazher \\ Mahasiswa Program Studi S1 Ekonomi Islam-Fakultas Ekonomi dan Bisnis-Universitas Airlangga \\ Email : syelvi.salama-10@feb.unair.ac.id \\ Noven Suprayogi \\ Departmen Ekonomi Syariah-Fakultas Ekonomi dan Bisnis-Universitas Airlangga \\ Email : noven.suprayogi@feb.unair.ac.id
}

\begin{abstract}
:
The purpose of this study was to determine how the pattern of financial planning and management of ethnic Arab families in Surabaya. This study used descriptive qualitative approach. The data collection is done by Interview and observation. The analysis technique used is the domain analysis techniques, taxonomy and componential.

The results of this study there are some interesting phenomena to be discussed related to the pattern of financial planning and management arab ethnic family in Surabaya namely: managing income that the arab ethnic family uphold the principles to qowwam husband was sustained to shalihaan wife. Managing highly prioritize the settlement of this case is the most important prior to meeting the needs of the family. Managing dream has rules of jurisprudence life priorities, namely mukhodima ahamminal Muhin. Managing surplus and deficit has a principle to prioritize investment of the savings. managing contigencie social capital as a protection of the family.
\end{abstract}

\section{Keywords : Planning, Management, Finance Family}

\section{PENDAHULUAN}

\section{Latar Belakang}

Membuat suatu perubahan dalam kondisi perekonomian Indonesia, harus dimulai dari satuan terkecil, yaitu keluarga. (Ghozie, 2013:30). Keluarga adalah unit organisasi terkecil yang ada dimasyarakat, sedangkan menurut (Horton dkk), bahwa keluarga adalah suatu system norma dan tata cara yang diterima untuk menyelesaikan sejumlah tugas penting. (Chester dan Paul, 2006:267). Keluarga muslim berbeda dengan keluarga yang di dalamnya tidak melaksanakan syariat islam. Kelvarga muslim didirikan atas dasar nilai-nilai keimanan, keutamaan yang mulia, akhlak yang baik, perilaku yang luhur, dan kebaikan unsur-unsur sosial lainnya. Semua unsur itu berinteraksi dalam sebuah rumah tangga sehingga terwujudnya rasa aman, tentram, saling mengasihi, dan mencintai karena Allah SWT. Dengan ini terwujudlah kehidupan yang sejahtera didunia dan mampu berpartisipasi dalam memakmurkan bumi sebagaimana diperintah Allah SWT, serta mendapat kebahagiaan di surga bagi kelvarga dan keturunannya yang beriman (Syahatah, 1998:37).

Ada beberapa alasan mengapa perencanaan keluarga diperlukan sehingga menjadi bagian penting dalam rumah tangga (tadbir al-manzil) seorang muslim. Salah satunya yaitu sebagai keluarga muslim yang taat, perencanaan merupakan salah satu bagian usaha

1) Jurnal ini merupakan bagian dari skripsi yang ditulis Syelvi Salama Binti Abdullah Bazher. NIM:

041014031, yang diuji pada 8 Juni 2016 
Bazher, et al/Jurnal Ekonomi Syariah Teori dan Terapan Vol. 4 No. 3 Maret 2017: 203-218; BAGAIMANA POLA PERENCANAAN DAN PENGELOLAAN KEUANGAN KELUARGA MUSLIM ETNIS ARAB YANG BERPROFESI USTADZ DAN DOKTER DI SURABAYA

manusia untuk mengubah keadaan menjadi lebih baik, sebagaimana firman Allah SWT dalam surat Ar Rad ayat 11

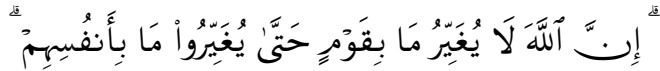
inna allāha lā yughayyiru mā biqawmin hattōa yughayyirū mā bianfusihim

"...Sesungguhnya Allah tidak
merobah Keadaan sesuatu kaum
sehingga mereka merobah keadaan
yang ada pada diri mereka
sendiri..."(QS. Ar-Rad : 11 )
(Departemen Agama RI)

Pada ayat di atas telah dijelaskan perintah Allah SWT terhadap manusia untuk merencanakan terlebih dahulu apa yang akan diperbuat di masa depan. Berikhtiar secara maksimal dengan melakukan perencanaan untuk situasi terburuk dan berharap untuk yang terbaik, setelah itu bertawakal kepada Allah SWT dengan sebenar-benarnya. (Syifa, 2011:211

Suami sebagai kepala keluarga berkewajiban untuk bekerja dengan baik melalui usaha yang baik dan halal. Oleh karena itu seorang laki-laki dijadikan pemimpin bagi wanita, sebagaimana firman Allah SWT dalam surat An-nisaa' ayat 34 berikut ini.

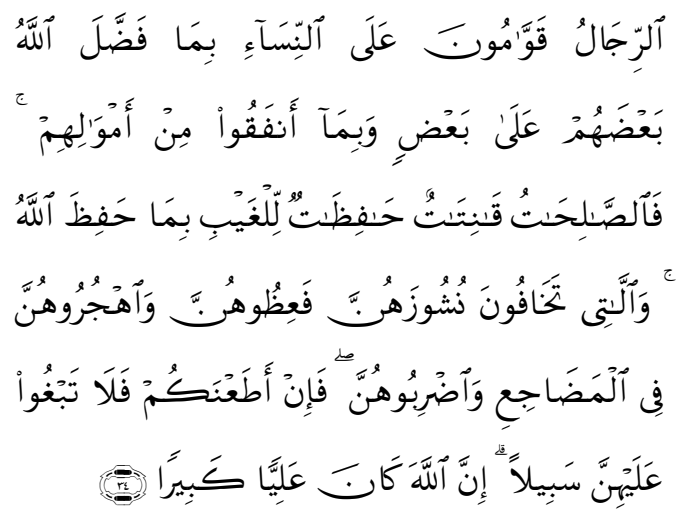

alrrijālu qawwōmūna 'alā alnnisāa-i bim $\overline{\bar{a}}$ fadhdhala allāhu ba'dhahum 'alā ba'dhin wabimā anfaqū min amwōalihim fālshshālihātu qā̄nitạtun hāfizhātun lilghaybi bim $\underline{\bar{a} h a f i z h h a}$ allāhu wāllāâtī takhāfūna nusyūzahunna fa'izhūhunna wauhjurūhunna fi almadāji'i waidhribūhunna fa-in atha'nakum falā tabghū 'alayhinna sabilan inna allāha kōna 'aliyyan kabīrān

"kaum laki-laki itu adalah pemimpin bagi kaum wanita, oleh karena Allah telah melebihkan sebahagian mereka (laki-laki) atas sebahagian yang lain (wanita), dan karena mereka (lakilaki) telah menafkahkan sebagian dari harta mereka. sebab itu Maka wanita yang saleh, ialah yang taat kepada Allah lagi memelihara diri ketika suaminya tidak ada, oleh karena Allah telah memelihara (mereka). wanita-wanita yang kamu khawatirkan nusyuznya, Maka nasehatilah mereka dan pisahkanlah mereka di tempat tidur mereka, dan pukullah mereka. kemudian jika mereka mentaatimu, Maka janganlah kamu mencari-cari jalan untuk menyusahkannya. Sesungguhnya Allah Maha Tinggi lagi Maha besar." (Qs.An-Nisaa:34) (Departemen Agama RI)

Orang-orang arab yang bermukim di Nusantara rata-rata berasal dari Hadramaut (Yaman) dan hanya sedikit yang berasal dari Maskat (tepian teluk Persia), Hijaz, Mesir atau dari pantai Timur Afrika. Orang-oarang Arab yang berasal dari hadramaut ke Indonesia terjadi pada akhir abad ke-18. Dengan jumlah yang cukup banyak mereka menyebar ke beberapa kota terutama Palembang, Pontianak, Batavia, Pekalongan, Surabaya, Sumenep dan lain-lain.(van, 1989:1) Suku arab yang tinggal di Indonesia adalah warga negara 
Bazher, et al/Jurnal Ekonomi Syariah Teori dan Terapan Vol. 4 No. 3 Maret 2017: 203-218; BAGAIMANA POLA PERENCANAAN DAN PENGELOLAAN KEUANGAN KELUARGA MUSLIM ETNIS ARAB YANG BERPROFESI USTADZ DAN DOKTER DI SURABAYA

indonesia yang memiliki keturunan etnis arab dan etnis pribumi Indonesia. Pada mulanya mereka umumunya tinggal di perkampungan Arab yang tersebar di berbagai kota di Indonesia yakni jakarta (Pekojan), Bogor (Empang), Surakarta (Pasar Kliwon), Surabaya (Ampel), Gresik (Gapura), Malang (Jagalan), Cirebon (Kauman), Mojokerto (Kauman), Yogyakarta, probolinggo (Diponogoro), Bondowoso, Palembang, Banda Aceh, Sigli, Medan, Banjarmasin, Makasar, Gorontalo, Ambon, Mataram, Kupang, Papua dan bahkan di Timor Timur. (van, 1989). Pada jaman penjajahan Belanda, mereka dianggap sebagai bangsa Timur Asing bersama dengan suku TionghoaIndonesia dan suku India-Indonesia, tapi seperti kaum etnis Tionghoa dan India, tidaklah sedikit yang berjuang membantu kemerdekaan Indonesia.(van, 1989)

Perempuan etnis arab mempunyai perilaku konsumtif terhadap barangbarang sekunder dan bersifat gengsi dikalangan mereka sendiri misalnya dalam hal berpenampilan. Perilaku konsumtif istri mendorong kaum suami memiliki loyalitas dan produktivitas yang tinggi dari usaha mereka agar mampu memenuhi tuntutan dari kaum wanitanya, karena pada masyarakat etnis arab suami yang harus memenuhi kewajiban memberi nafkah pada keluarga. (Suryaningrum, 2008)

Maka dengan ini, peran istri sebagai manager kevangan dalam rumah tangga diharapkan mampu mengatur dan mengelola keuangan kelvarga yang diberikan kepala kelvarga untuk pemenuhan kebutuhan baik dalam jangka pendek maupun jangka panjang. Bagaimana Pola Perencanaan dan Pengelolaan Keuangan Keluarga Muslim Etnis Arab di Surabaya.

\section{LANDASAN TEORI}

Perencanan

keuangan

didefinisikan sebagai suatu proses untuk mencapai tujuan hidup melalui pengaturan keuangan yang sesuai.(Adler dan Lutfi, 2009:1). Perencanaan keuangan juga didefinisikan sebagai proses merencanakan keuangan untuk mencapai tujuan-tujuan keuangan jangka pendek maupun jangka panjang. (Senduk, 2009:3). Management merupakan suatu seni maka setiap individu atau keluarga mempunyai seni masing-masing dalam mengelola keuangan keluarga. Akan tetapi pada dasarnya kegiatan management meliputi perencanaan, pelaksanaan atau pengalokasian dan pengendalian serat evaluasi (POAC), demikian juga dengan manajemen keuangan keluarga tidak lepas dari kegiatan tersebut yaitu mulai perencanaan sampai pemanfaatan atau pengalokasian dana maupun pencairan dana, sampai pada mengevaluasi kinerja keuangan keluarga. (Rodhiyah, 2012:29)

Perencanaan keuangan islami adalah sebuah proses merencanakan dan mengelola keuangan keluarga menurut aturan Al-quran dan Hadits untuk mencapai tujuan-tujuan keuangan kehidupan dunia akhirat. Dapat dipahami bahwa perencanaan keuangan 
Bazher, et al/Jurnal Ekonomi Syariah Teori dan Terapan Vol. 4 No. 3 Maret 2017: 203-218; BAGAIMANA POLA PERENCANAAN DAN PENGELOLAAN KEUANGAN KELUARGA MUSLIM ETNIS ARAB YANG BERPROFESI USTADZ DAN DOKTER DI SURABAYA

sebenarnya sudah diperintahkan sejak dahulu pada masa Rasulullah SAW, karena manusia selain diharuskan untuk memikirkan dirinya juga diharuskan untuk memikirkan generasinya yang mendatang. Jangan sampai generasi yang nantinya akan ditinggalkan menjadi generasi yang lemah dan akan menyusahkan orang lain, karena apabila generasi muslim yang ditinggalkan dalam keadaan lemah maka dapat menjadikan generasi tersebut kufur karena kemiskinan mendekati kekufuran. Dalam Al-Qur'an Qs Yusuf 12 ayat 47-49

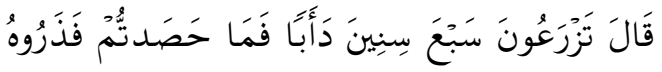

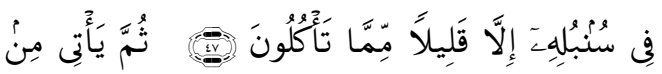

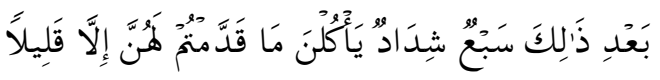

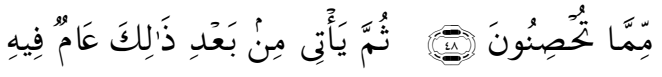

$$
\begin{aligned}
& \text { يُنَاثُ ألنَّاسُ وَفِفِيهِ يَعْصِرُونَ }
\end{aligned}
$$

qā̄la tazra'ūna sab'a sinīna da-aban famāhashadtum fadzarūhu fi sunbulihi illā qailian mimm $\underline{\bar{a}}$ ta/kulūna. 48. tsumma ya/tī min ba'di dzālika sab'un syidādun ya/kulna mā qaddamtum lahunna illā qallan mimmā tuhsinūna. 49. tsumma ya/tī min ba'di dzālika 'āmun fihi yughātsu alnnō̄su wafihi ya'shirūna

"Yusuf berkata: "supaya kamu bertanam tujuh tahun lamanya sebagimana biasa; Maka apa yang kamu tuai hendaklah kamu biarkan dibulirnya kecuali sedikit untuk kamu makan. Kemudian sesudahnya itu akan datang tujuh tahun yang amat sulit, yang menghabiskan apa yang kamu simpan untuk menghadapinya (tahun sulit), kecuali sedikit dari bibit gandum yang kamu simpan. Kemudian setelah itu akan datang tahun yang padanya manusia diberi hujan dan dimasa itu mereka memeras anggur" (Qs Yusuf :47-49) (Departemen Agama RI)

Dari ayat diatas juga dapat dipahami bahwa penerapan perencanan kevangan sebenarnya sudah dilaksanakan jauh sebelum para cendikiawan barat melakukannya, yaitu pada masa Nabi Yusuf AS. Allah SWT juga memperingati hambanya untuk melakukan pencegahan terhadap kesulitan yang akan datang yang bukan dimaksudkan untuk menghilangkannya, tapi untuk mencegah dan meminimalisir risiko kesulitan yang akan dihadapi, jika perencanaan keuangan sangat sesuai dengan prinsip syariah yang ada dan tidak perlu ada kekhawatiran bahwa perencanaan keuangan adalah pelajaran yang diterapkan oleh orangorang konvensional. (Pratiwi, 2010:39)

Pendapatan adalah seluruh pemasukan atau penghasilan yang diperoleh. Mengenali penghasilan sama saja dengan untuk mem-break down seluruh nominal dan sumber penghasilan yang dimiliki. Proses ini sangatlah penting untuk dilakukan. Karena untuk dapat mengelola keuangan keluarga muslim yang islami, pintu gerbangnya ada di pendapatan. Bila tidak melakukan proses ini maka tidak dapat mengelola pemanfaatan pendapatan dengan baik. Pendapatan merupakan kunci pengelolaan keuangan keluarga. Dari pendapatan inilah akhirnya harus mengatur biaya rutin, biaya antisipasi, investasi akhirat dan biaya investasi dunia. 
Bazher, et al/Jurnal Ekonomi Syariah Teori dan Terapan Vol. 4 No. 3 Maret 2017: 203-218; BAGAIMANA POLA PERENCANAAN DAN PENGELOLAAN KEUANGAN KELUARGA MUSLIM ETNIS ARAB YANG BERPROFESI USTADZ DAN DOKTER DI SURABAYA

Penghasilan yang diperoleh haruslah halal dan thoyib.

Allah SWT menyediakan bumi lengkap dengan isinya dan kiranya manusia tidak mengikuti kerajaan dan jejek syaitan yang selalu menggoda manusia agar mau mengharamkan sesuatu yang telah dihalalkan Allah SWT dan mengharamkan kebaikan-kebaikan yang dihalalkan Allah SWT dan syitan juga mengehendaki manusia agar terjerumus dalam lembah kesesatan. (Qardhawi, 1993: 45). Maka dari itu dalam mencari nafka manusia boleh menggunkan sumber daya yang ada dibumi dengan cara yang halal dan baik yang telah dikaruniakan oleh Allah SWT.

Hutang merupakan kewajiban dan harus ditepatkan sebagai prioritas pertama. Jika nilainya kecil, bisa dibayar lunas pada kesempatan pertama. Namun, sekiranya jumlahnya besar, dapat dibayarkan secara angsuran berkala sesuai dengan kesepakatan pemberi utang (Luqyan Tamanni, 2013:54). Setiap muslim dianjurkan untuk menyeimbangkan pendapatan dengan pengelvaran dan vang pendapatan dengan belanja, agar tidak terpaksa berhutang dan merendahkan dirinya dihadapan orang lain. (Qardhawi, 1997:149)

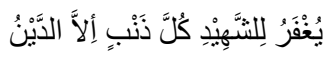

yugfaru lisy-syahiididi kulla zabbin illaddainu

"bagi para syuhada akan dihapuskan seluru dosa mereka kecuali utangpiutang (yang belum mereka bayar)" (HR Muslim)
Hadits ini menandakan betapa pentingnya memenuhi hak sesama manusia, terutama dalam masalah uang, sampai mereka wafat di jalan Allah SWT. Nabi SAW melarang manusia menyalati jenazah orang yang meninggal dunia dengan meninggalkan utang dan tidak ada harta peninggalan orang itu untuk melunasinya, juga tidak ada seorang dari kaum muslimin yang menjamin pelunasan utangnya (Qardhawi, 1997: 150).

Islam merupakan agama yang rahmatan lil 'alamin, yaitu memberikan rahmat bagi semua makhluk, sehingga dari makna tersebut dapat diartikan bahwa islam sangat peduli terhadap kehidupan kaum dhuafa. (Hidayat, 2010). Di dalam setiap harta manusia sudah tercatat didalamya hak-hak kaum yang lemah, seperti fakir miskin, orang tua, atau anak yatim. Hak ini bisa ditunaikan dengan menyalurkan melalui instrumeninstrumen ZISWAF (Zakat, Infaq, Shadaqah, dan Wakaf) yang mekanisme pengumpulan dan penyalurannya sudah diatur dalam islam. ZISWAF juga merupakan amal yang menyebabkan adanya keberkahan dalam harta dan pendapatan.seringkali merasahkan harta cepat habis atau merasa kurang, bisa jadi karena dari harta tersebut masih ada hakhak yang belum terpenuhi. Firman Allah SWT dalam Al-Qur'an suarat Al-baqarah ayat 276 , 
Bazher, et al/Jurnal Ekonomi Syariah Teori dan Terapan Vol. 4 No. 3 Maret 2017: 203-218; BAGAIMANA POLA PERENCANAAN DAN PENGELOLAAN KEUANGAN KELUARGA MUSLIM ETNIS ARAB YANG BERPROFESI USTADZ DAN DOKTER DI SURABAYA

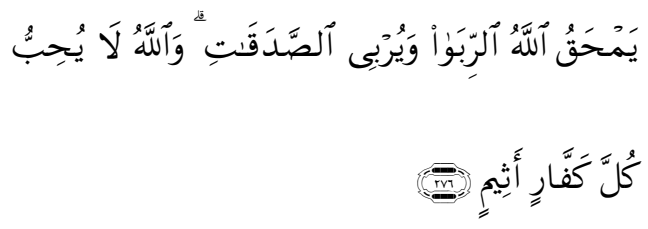

yamhaqu allāhu alrribā wayurbì alshshadaqāti wāllāhu lā yuhibbu kulla kaffārin atsīmin

"Allah memusnahkan Riba dan menyuburkan sedekah. dan Allah tidak menyukai Setiap orang yang tetap dalam kekafiran, dan selalu berbuat dosa."(QS. Al-Baqarah; 276) (Departemen Agama RI)

Islam mengajarkan untuk selektif dalam membelanjakan harta. Dalam pengeluaran, yang perlu diperhatikan seseorang adalah prioritas, bukan berdasarkan keinginan, tetapi berdasarkan kebutuhan, baik itu jangka pendek, menengah, maupun jangka panjang. Selain itu, pengeluaran juga harus memperhatikan aspek keseimbangan antara kehidupan dunia dan akhirat. Karena untuk mencapai kehidupan akhirat yang baik, kita juga harus mempunyai kehidupan dunia yang baik.(Pratiwi, 2010:3)

Kelebihan dana yang terjadi pada neraca rumah tangga mungkin saja terjadi di sela-sela masa neraca itu berlaku. Kelebihan dana sebaiknya tidak ditimbun, karena dalam islam hukumnya haram. Oleh karena itu, ibu rumah tangga harus pandai mencari jalan untuk mengembangkan kelebihan dana demi kemaslahatan rumah tangga dan masyarakat (Syahatan, 1998:105).

Salah satu tujuan dari pembuatan anggaran adalah untuk menjaga agar tidak mengalami defisit, yaitu ketika pengelvaran lebih besar dari pada pemasukan. Inilah untungnya membuat anggaran, karena bisa dilakukan pencegahan agar jangan sampai pengeluaran keluarga lebih daripada pemasukannya.(Rini, 2014:68).

Menurut Rodhiyah (2012:31) ketika pengeluaran vang melebihi penerimaan vang, maka perlu dilakukan pencairan dana, dan salah satu alternatifnya adalah dengan hutang. Hutang adalah dana dari pihak ketiga yang pada waktu jatuh tempoh harus dikembalikan. Hutang memang bisa menjadi dewa penyelamat, tetapi pada waktu lain hutang bisa menjadi awal malapetaka yang akan meporakporandakan keuangan keluarga. Hutang bukan hal yang haram tetapi perlu disiasati dan disikapi, sehingga tidak akan merusak suatu keluarga. Mungkin sebuah keluarga memiliki utang kepada pihak lain yang harus dicicil setiap bulanya. Pembayaran cicilan utang ini harus diprioritaskan untuk memastikan bahwa hutang tersebut akan dibayarkan (Rini, 2014:66).

Setiap saat seseorang berhadapan dengan keadaan yang diluar dugaan, misalnya keluarga yang sakit dan harus ditolong, pulang kampung mendadak, kendaraan 'diserempet' orang, tau hal-hal lain yang tidak bisa direncanakan. Namun salah satu yang paling memberatkan adalah ketika kehilangan sumber pendapatan utama atau transisi pindah dari satu pekerjaan ke pekerjaan lain. Hal ini bisa dan mungkin 
Bazher, et al/Jurnal Ekonomi Syariah Teori dan Terapan Vol. 4 No. 3 Maret 2017: 203-218; BAGAIMANA POLA PERENCANAAN DAN PENGELOLAAN KEUANGAN KELUARGA MUSLIM ETNIS ARAB YANG BERPROFESI USTADZ DAN DOKTER DI SURABAYA

saja terjadi, baik untuk sementara waktu maupun untuk jangka panjang yang relatif lama. Baiknya dana emergensi ini disimpan dalam bentuk tabungan yang tidak terlalu mudah untuk diakses dan jika diperlukan bisa segera dicairkan. Dana darurat harus ada karena dana darurat sangatlah berguna saat tidak mempunyai pendapatan dalam jangka waktu tertentu sementara kebutuhan tetap harus dipenuhi. Besarnya dana darurat ini berbeda-beda tergantung kebutuhan dan gaya hidup tiap keluarga (Aulia, 2009:46).

Asuransi merupakan sistem proteksi keuangan keluarga dan harta-benda dari situasi yang tidak di harapkan dengan memberikan santunan atau ganti rugi finansial. Perlindungan dalam islam dikenal sebagai takaful. Dalam sistem syariah atau takaful, asuransi adalah suatu ikhtiar dan bentuk solidaritas bersama terhadap kemalangan yang diderita oleh anggota komunitas atau masyarakat yang lain. Hal ini merupakan landasan utama dari diperbolehkannya sistem asuransi dalam ekonomi islam. Asuransi syariah atau takaful mempunyai paradigma yang sangat berbeda dengan sistem asuransi konvensional, terutama aspek pengelolaan risiko (Luqyan Tamanni, 2013:121)

\section{METODE PENELITIAN}

Ruang lingkup penelitian terkait dengan rumusan masalah. Rumusan masalah dalam penelitian ini yaitu bagaimana pola perencanaan pengelolaan keuangan keluarga muslim etnis arab di surabaya. Rumusan masalah tersebut digunakan sebagai pedoman dalam penentuan ruang lingkup penelitian. Dengan demikian, akan diketahui pola perencanan pengelolan kevangan kelvarga muslim etnis arab dalam menjalankan aktivitas keuangan dalam keluarga.

Data yang digunakan dalam penelitian kualitatif ini adalah data primer dan sekunder. Data primer adalah data dari hasil wawancara dan observasi langsung dilapangan. Sedangkan data sekunder berdasarkan studi literatur, jurnal dan browsing internet. Data primer didapat melalui metode wawancara yang memungkinkan peneliti bertatap muka langsung dengan informan untuk menggali informasi dengan lebih mendalam sehingga mendapat hasil yang valid.

Dalam penelitian ini digunakan beberapa teknik analisis (Sugiyono, 2011:256) seperti;

a. Analisis Domain

Tujuaan analisis domain adalah untuk memperoleh gambaran yang umum dan menyeluruh dari obyek/penelitian atau situasi sosial. Pada analisis ini peneliti menetapkan domain tertentu sebagai pijakan untuk penelitian selanjutnya. (Sugiyono, $2011: 256)$. Analasis domain dalam penelitian ini digunakan untuk memperoleh gambaran umum mengenai pola perencanaan dan pengelolaan keuangan keluarga muslim etnis arab di surabaya. 
Bazher, et al/Jurnal Ekonomi Syariah Teori dan Terapan Vol. 4 No. 3 Maret 2017: 203-218; BAGAIMANA POLA PERENCANAAN DAN PENGELOLAAN KEUANGAN KELUARGA MUSLIM ETNIS ARAB YANG BERPROFESI USTADZ DAN DOKTER DI SURABAYA

b. Analisis Taksonomi

Domain yang dipilih tersebut selanjutnya dijabarkan menjadi lebih rinci, untuk mengetahui struktur internalnya. Hal ini dilakukan dengan cara observasi. (Sugiyono, 2011:261). Analisis taksonomi dalam penelitian ini digunakan untuk memperoleh lebih spesifik yang diperoleh dari analisis domain.

c. Analisis Komponensial

Analisis ini adalah mencari ciri spesifik pada setiap struktur internal dengan cara mengkontrak antar elemen. Hal ini dilakukan dengan cara observasi dan wawancara. (Sugiyono, 2011:264). Dalam penelitian ini analisis komponensial digunakan untuk mengidentifikasi kontras atau perbedaan jawaban pada dua keluarga muslim etnis arab yang berbeda profesi.

\section{HASIL DAN PEMBAHASAN}

Dari hasil analisis data didapat beberapa fenomena yang menarik untuk dibahas terkait dengan Pola Perencanaan dan Pengelolaan Keuangan Keluarga etnis arab di Surabaya yaitu :

1. Prinsip Manajemen Pendapatan (Managing Income) Keluarga Etnis Arab adalah prinsip ke Qowwaman suami itu topang ke shalihaan istri

2. Prinsip Manajemen Kebutuhan (Managing Need) Keluarga Etnis Arab adalah Prinsip memprioritaskan pelunasan hutang sebelum dibelanjakan untuk kebutuhan primer.
3. Prinsip Manajemen Impian (Managing Dream) Kelvarga Etnis Arab adalah prinsip mukadimah aham minal muhim selalu mendahulukan yang paling penting dari yang penting.

4. Prinsip Manajemen Surplus dan Defisit (Managing Surplus and Defisit) Kelvarga Etnis Arab adalah Prinsip memprioritaskan investasi dari pada tabungan

5. Prinsip Manajemen Ketidakpastian ( Managing Contingencie) Kelvarga Etnis Arab adalah bergantung pada faktor modal sosial.

Dari kelima prinsip tersebut maka memunculkan pola perencanaan dan pengelolaan keuangan keluarga etnis arab yang khas dari pada etnis lainnya, yaitu sebagai berikut:

\section{Manajemen Pendapatan (Managing Income)}

Prinsip yang digunakan dalam Manajemen Pendapatan (Managing Income) pada keluarga etnis arab di surabaya adalah prinsip ke qowwaman suami itu topang ke shalihaan istri. Kelvarga etnis arab sangat memegang teguh prinsip tersebut. Prinsip ini merupakan ciri khas didalam keluarga etnis arab. Prinsip yang diajarkan oleh orang tua dan mayoritas keluarga etnis arab sangat memegang teguh dan menerapkan prinsip tersebut. Prinsip yang mewajibkan suami untuk bertanggung jawab sepenuhnya dalam mencari nafkah yang halal lagi baik dan menuntut istri dirumah untuk mendidik serta merawat anak-anaknya. 
Bazher, et al/Jurnal Ekonomi Syariah Teori dan Terapan Vol. 4 No. 3 Maret 2017: 203-218; BAGAIMANA POLA PERENCANAAN DAN PENGELOLAAN KEUANGAN KELUARGA MUSLIM ETNIS ARAB YANG BERPROFESI USTADZ DAN DOKTER DI SURABAYA

Qawwamuna adalah bentuk jamak dari kata Qawwam yang terambil dari kata qaama. Kata ini satu sama lain berkaitan. Seperti halnya perintah shalat menggunkana akar kata itu. Perintah tersebut bukan berarti perintah untuk mendirikan shalat, tetapi melaksanakannya dengan sempurna, memenuhi segala syarat, rukun dan sunnah-sunnahnya. Seorang yang melaksanakan tugas atau apa yang diharapkan darinya dinamai Qaim. Jika seseorang tersebut melaksakan tugas dengan sesempurna mungkin, berkesinambunngan dan berulang-ulang maka dinamakan qawwam. Dalam surat An-nisa ayat 34 menggunkan bentuk jamak dari qawwamuna yang sejalan dengan makna ar-rajul yang berarti banyak lelaki. Dan seringkali kata ini juga diaartikan sebagai pemimpin. (Shihab, 2009: 511)

Kepemimpinan suami terhadap isrtinya sudah menjadi fitra yaitu demi kemaslahaatan istri. Oleh sebab itu Allah SWT mengutamakan suami atas istri dengan segala potensi dan kemampuan yang dianugrahkan Allah SWT kepadanya, seperti kekuataan dalam mencari nafkah dan sebagainya. Begitu juga dengaan istri melakukan segala sesuatu sesuai dengan kodratnya sebagai wanita, seperti melahirkan mendidik anak yang merupakan amanah dan rezeki dari Allah SWT. (www.pcimmesir.com)

Kepemimpinan seorang suami membawa tanggung jawab sepenuhnya dalam bekerja mencari nafkah yang baik dari usaha yang halal lagi baik untuk dapat mencukupi biaya hidup anggota keluarga dan mewajibkan istri dirumah untuk mendidik serta merawat anak-anak. Oleh karena itu mayoritas istri di dalam keluarga etnis arab lebih banyak beraktivitas didalam rumah dari pada beraktivitas diluar rumah. Hal ini dapat dilihat dari hasil wawancara dengan kedua Keluarga. Keluarga ustadz menyatakan bahwa kalangan arab memiliki prinsip ke qowwam suami itu topang ke shalihaan istri. Ini adalah nilainilai orang tua yang diajarkan kepadanya dan informan masih memegang teguh prinsip itu. Prinsip yang menuntut suami untuk bertanggung jawab sepenuhnya dalam mencari nafkah dan mewajibkan istri dirumah untuk mendidik serta merawat anak-anaknya. Berdasarkan penjelasan informan dalam komunitas arab jika bicara secara ekonomi laki laki yang lebih dominan, perempuan tinggal menerima hak-haknya, dipenuhi segala keperluannya dan memang harus seperti itu.

Bahwasanya prinsip qawwam menjadi prinsip yang dipegang dan diterapkan oleh mayoritas keluarga etnis arab. Dengan prinsip qawwam tersebut mewajibkan suami untuk bekerja mencari nafkah yang halal dan baik maka dari itu kelvarga etnis arab mempunyai prinsip kehati-hatian dalam memperoleh rezeki. Tidak menghalalkan segala cara dan juga menjauhi subhat dalam perolehannya. Motivasi dan niat merupakan salah satu hal yang mempengaruhi dalam 
Bazher, et al/Jurnal Ekonomi Syariah Teori dan Terapan Vol. 4 No. 3 Maret 2017: 203-218; BAGAIMANA POLA PERENCANAAN DAN PENGELOLAAN KEUANGAN KELUARGA MUSLIM ETNIS ARAB YANG BERPROFESI USTADZ DAN DOKTER DI SURABAYA

menghasilkan sumber pendapatan. Motivasi kedua keluarga dalam memperoleh pendapatan selain untuk memenuhi kebutuhan hidup juga sebagai sarana beribadah, menjaga dakwa yang dilakukannya dan juga untuk kesejahteraan keluarga dimasa depan.

Prinsip kehati-hatian dalam keluarga etnis arab diterapkan agar harta yang didapatkan menjadi halal dan baroka. Dapat dilihat keluarga etnis arab lebih memprioritaskan kehalalan dan keberkahan dalam memperoleh rezeki agar harta yang didapat menjadi Halalan Thoyiban Mubaraka Khasiron. Keluarga etnis arab menerapkan prinsip Halalan Thoyiban Mubaroka Khashiron dalam memperoleh pendapatan. Halalan Thoyiban Mubaroka Khashiron yaitu halal tidak mendzolimi orang lain, halal lagi baik serta harta yang diperoleh banyak dan barokah. Hal ini sesuai dengan teori yang dikemukakan Yusuf Qardhawi (1993:143) bahwa semua jalan untuk berusaha mencari uang yang tidak menghasilkan manfaat kepada seseorang kecuali dengan menjatuhkan orang lain, adalah tidak dibenarkan dan semua jalan yang saling mendatangkan manfaat antara individu-individu dengan saling relamerelahkan dan adil adalah dibenarkan. (Qardhawi, 1993:143).

\section{Manajemen Kebutuhan (Managing Needs)}

Prinsip yang digunakaan dalam Manajemen Kebutuhan (Managing Need) pada keluarga etnis arab di Surabaya adalah prinsip memprioritaskan pelunasan hutang terlebih dahulu sebelum dibelanjakan untuk kebutuhan primer lainnya. Keluarga etnis arab sebelum memenuhi kebutuhan pokok lebih memprioritas pelunasan hutang hal ini merupakan yang paling utama, karena hutang adalah hak antara manusia dengan manusia sedangkan pembayaran zakat adalah hak antara Allah SWT yang diberikan kepada yang berhak menerimanya. Menurut Luqyan Tamanni (2013:54) pelunasan hutang merupakan prioritas yang paling utama dalam keuangan keluarga. Setelah hutang prioritas kedua yaitu pembayaran zakat. Dalam sebuah hadits riwayat muslim, "bagi para syuhada akan dihapuskan seluru dosa mereka kecuali utang-piutang (yang belum mereka bayar)". (HR Muslim). Hadits ini menandakan betapa pentingnya memenuhi hak sesama manusia, terutama dalam masalah hutang, sampai mereka wafat di jalan Allah SWT. Nabi melarang manusia menyalati jenazah orang yang meninggal dunia dengan meninggalkan utang dan tidak ada harta peninggalan orang itu untuk melunasinya, juga tidak ada seorang dari kaum muslimin yang menjamin pelunasan utangnya. (Qardhawi, 1997:150).

\section{Manajemen Impian (Managing Dream)}

Prinsip yang digunakan dalam Manajemen Impian Keluarga (Managing Dream) pada keluarga etnis arab di Surabaya adalah memiliki prinsip fiqih prioritas yaitu mukadimah aham minal muhim selalu mendahulukan yang paling 
Bazher, et al/Jurnal Ekonomi Syariah Teori dan Terapan Vol. 4 No. 3 Maret 2017: 203-218; BAGAIMANA POLA PERENCANAAN DAN PENGELOLAAN KEUANGAN KELUARGA MUSLIM ETNIS ARAB YANG BERPROFESI USTADZ DAN DOKTER DI SURABAYA

penting dari yang penting. Keluarga etnis arab selalu selektif dalam pembelanjaan sangat memperhatikan skala prioritas dan selalu membedakan mana yang merupakan kebutuhan dan mana yang keinginan. Hal ini sesuai dengan firman Allah SWT dalam surat al-furqon ayat 67,

"dan orang-orang yang apabila membelanjakan (harta), mereka tidak berlebihan, dan tidak (pula) kikir, dan adalah (pembelanjaan itu) di tengahtengah antara yang demikian".

Ayat tersebut menjelaskan agar

dalam memenuhi kebutuhan tidak boleh terlalu kikir, boros dan juga berlebihan namun harus seimbang sesuai kebutuhan bukan keinginan untuk menuruti hawa nafsu semata. Iman yang ada dalam diri seorang muslim dapat menjadikan dirinya melawan hawa nafsu dari keinginan duniawi. Allah SWT berfirman dalam surat al-A'raf ayat 31,

"Hai anak Adam, pakailah pakaianmu yang indah di Setiap (memasuki) mesjid, Makan dan minumlah, dan janganlah berlebihlebihan Sesungguhnya Allah tidak menyukai orang-orang yang berlebihlebihan".

Fiqih prioritas menurut Yusuf

Qardawi (1996:4) ialah meletakkan segala sesuatu pada peringkatan dengan adil, dari segi hukum, nilai, dan pelaksanaannya. Pekerjaan yang mulamula dikerjakan harus didahulukan, berdasarkan penilaian syari'ah yang shahih, yang diberikan petunjuk oleh wahyu dan diterangi oleh akal. Sehingga sesuatu yang tidak penting, tidak didahulukan atas sesuatu yang penting. Sesuatu yang tidak kuat (marjuh) tidak didahulukan atas sesuatu yang kuat (rajih). Kemudian sesuatu yang "biasabiasa" saja tidak didahulukan atas sesuatu yang utama atau yang paling utama. Sesuatu yang semestinya didahulukan harus didahulukan dan yang semestinya diakhirkan harus diakhirkan. Sesuatu yang kecil tidak perlu dibesarkan dan sesuatu yang penting tidak boleh diabaikan. Setiap perkara mesti diletakkan di tempatnya dengan seimbang dan lurus, tidak lebih dan tidak kurang (Qardhawi, 1996:4).

Berdasarkan pengamataan dan hasil wawancara dalam menghadapi imipian atau keinginan keluarga, keluarga etnis arab dalam penelitian ini terlihat bahwa kedua keluarga memiliki skala prioritas dalam mengelola keuangan selalu memprioritaskan kebutuhan dari pada keinginan. Namun ada perbedaan dalam mengelola skala prioritas, jika dalam keluarga ustadz selalu melakukan musyawarah atau berdiskusi dengan anak-anaknya untuk mengambil suatu keputusan khususnya terkait masalah keinginan kelvarga. Berbeda dengan keluraga dokter tidak ada musyawarah dan keluarga dokter lebih mendahulukan kebutuhan dari pada keinginan terlihat dari keadaan rumah yang belum banyak terisi perabotan. Kedua keluarga memiliki rencana masa depan yang ingin dicapai dan sebenarnya mampu untuk dicapai namun pada realitasnya mereka lebih mendahulukan kebutuhaan yang lebih penting. Jika keluarga ustadz ingin merealisasikan keinginan untuk berhaji dengaan kelas vvip mengupayakan 
Bazher, et al/Jurnal Ekonomi Syariah Teori dan Terapan Vol. 4 No. 3 Maret 2017: 203-218; BAGAIMANA POLA PERENCANAAN DAN PENGELOLAAN KEUANGAN KELUARGA MUSLIM ETNIS ARAB YANG BERPROFESI USTADZ DAN DOKTER DI SURABAYA

dengan mewujudkannya namun ditahan dan lebih memprioritaskan pembangunan masjid dan sekolah. Banyak relasi beliau yang mengajak untuk berhaji dengan fasilitas vvip namun ditolaknya karena beliau merasa sudah sering berhaji. Sedangkan kelvarga dokter memiliki tujuan melunasi hutang kpr dengan cara mengatur keuangan baru dan memperketat pengeluaran.

\section{Manajemen Surplus dan Defisit (Managing}

\section{Surplus and Defisit)}

Prinsip yang digunakan dalam manajemen surplus dan defisit (managing surplus and defisit) pada keluarga etnis arab di Surabaya adalah prinsip memprioritaskan investasi dari pada tabungan. manfaat dari berinvestasi dirasa lebih besar daripada hanya disimpan ditabungan saja. Ketika surplus dijadikan modal untuk modal usaha kerabat sehingga kedua belak pihak dapat memperoleh manfaatnya. Berdasarkan pengamataan dan hasil wawancara dalam menghadapi surplus dan defisit yang terjadi, keluarga etnis arab dalam penelitian ini terlihat bahwa kedua keluarga memiliki kesadaran yang cukup dalam menabung dikemudian hari ada hal-hal yang mendadak atau mendesak agar dapat diantisipasi seperti sakit yang di luar jangkauan dan juga mengetahui bahwa tabungan itu penting sebagai salah satu sarana penyisihan vang yang harus dilakukan, namun kedua keluarga sama sama tidak memiliki tabungan khusus dengan alasan yang berbeda dan tidak menggunakan tabungan sebagai sarana untuk berinvestasi. Ketika surplus kedua keluarga lebih memilih berinvestasi. Kedua keluarga selama berkeluarga perna mengalami keadaan defisit. Ketika mengalami keadaan defisit keuangan kedua keluarga mempunyai solusi yang berbeda dalam mengatasinya, keluarga ustdaz mengatasinya dengan cara menghubungi beberapa kerabat dekat yang sifatnya pinjam dan segera mungkin melunasinya, sedangkan keluarga dokter mengatasinya dengan bersabar dan menunggu datangnya rezeqi. Menurutnya orang islam itu jika mensyukuri segala sesuatu yang didapat Allah SWT akan menambah nikmatnya.

\section{Manajemen Ketidakpastian (Managing Contigencies)}

Prinsip yang digunakan dalam manajemen ketidakpastian (managing contigencies) pada keluarga etnis arab di Surabaya adalah bergantung pada modal sosial. Hubungan kekeluargaan dan kekerabatan didalam keluarga etnis arab sangat erat. Tidak hanya antar anggota keluarga saja namun antar marga semangat keakrabannya dapat terlihat. Satu dengan lainnya saling akrab dan sering bersilaturahmi, diarisan keluarga, halal bihalal, pesta pernikahan atau pun di acara kajian. Modal sosial juga perna diterapkan pada zaman Rasulullah SAW dalam rangka mempererat Ukhuwwah (persaudaraan) kaum muhajirin dan Anshar dengan adanya unsur saling percaya (trust). Titik permulaan persaudaraan ini sebenarnya 
Bazher, et al/Jurnal Ekonomi Syariah Teori dan Terapan Vol. 4 No. 3 Maret 2017: 203-218; BAGAIMANA POLA PERENCANAAN DAN PENGELOLAAN KEUANGAN KELUARGA MUSLIM ETNIS ARAB YANG BERPROFESI USTADZ DAN DOKTER DI SURABAYA

telah dimulai pada fase mekkah dimana Rasulullah SAW melarang segala sesuatu yang memicu timbulnya kebencian. Islam menggangap orang mukmin terhadap mukmin lain sebagai saudara, karena membangun hubungan persahabatan yang akrab dan tolong-menolong dalam kebaikan adalah kewajiban bagi setiap muslim. Dalam hal ini ukhuwwah (persaudaraan) yang terbangun di antara umat islam menuntut mereka untuk saling mengenal (ta'aruf), saling bersosialisasi dan saling beramar makruf nahi munkar satu dengan yang lainnya. Di mana dalam islam, manusia tidak hanya di wajibkan untuk beribadah kepada Allah SWT semata namun lebih dari itu sebagai makhluk sosial, manusia juga diperintahkan untuk bersosialisasi, serta menjalin hubungan baik dengan orang lain. Bahkan dalam hal ini, islam tidak membatasinya hanya kepada sesama umat muslim saja, melainkan berlaku juga bagi semua umat manusia. Dalam hal mengenal satu sama yang lain tanpa membedakan suku bangsa. Dari sikap saling mengenal inilah, sebuah asosiasi dan jaringan akan mulai terbentuk. (Sanrego dan Taufik, 2016:139)

\section{Allah SWT berfirman dalam Surat}

Al-Hujurat ayat 13,

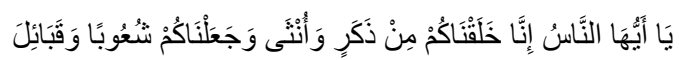

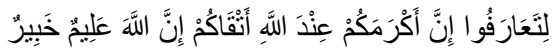

$$
\begin{aligned}
& \text { yaa ayyuhaa alnnaasus innaa } \\
& \text { khalaqnaakum min dzakarin } \\
& \text { wauntasaa waja'alnaakum } \\
& \text { syu'vuban waqabaa-ila lita'aaraafuu } \\
& \text { inna akramakum 'inda allahi } \\
& \text { atqaakum inna allaaha 'aliimun }
\end{aligned}
$$

"Hai manusia sesungguhnya kami menciptakan kammu dari seseorang laki-laki dan seorang perempuan dan menjadikan kamu berbangsa-bangsa dan bersuku-suku supaya kamu saling kenal-mengenal. Sesungguhnya orang yang paling mulia diantara kamu disisi Allah ialah orang yang paling bertaqwa diantara kamu. Sesungguhnya Allah Maha Mengetahui lagi Maha Mengenal" (Qs. AlHujuraat:13)

Pada ayat diatas Allah SWT menjelaskan bahwa manusia diciptakan oleh Allah SWT dalam keadaan berbedabeda agar mereka saling mengenal. Dimana sebagai makhluk sosial, manusia tidak bisa hidup sendiri tanpa mempedulikan hubungan dengan orang lain dari sinilah peran penting dari sebuah perkenalan sangat dibutuhkan. Dalam islam, salah satu perbuatan yang mampu memperkokoh hubungan manusia sehingga terbentuk sebuah jaringan yang kuat yaitu silaturahmi. Silaturrahmi mampu menumbuhkan sikap saling menghargai dan menyayangi diantara masyarakat yang merupakan pondasi pokok dari sebuah jaringan yang kuat. (Sanrego dan Taufik, 2016:140)

Berdasarkan pengamataan dan hasil wawancara dalam menghadapi ketidakpastian yang mungkin terjadi, kelvarga etnis arab dalam penelitian ini terlihat dalam proteksi yang dilakukan bergantung pada faktor modal sosial yaitu hubungan kekerabatan dan pertemanan. Ini merupakan dampak dari hobi yang dilakukan kedua keluarga yaitu bersilaturahim. Sebagaimana telah 
Bazher, et al/Jurnal Ekonomi Syariah Teori dan Terapan Vol. 4 No. 3 Maret 2017: 203-218; BAGAIMANA POLA PERENCANAAN DAN PENGELOLAAN KEUANGAN KELUARGA MUSLIM ETNIS ARAB YANG BERPROFESI USTADZ DAN DOKTER DI SURABAYA

dijelaskan di bab sebelumnya bahwa silaturahim memberikan banyak manfaat dan keberkahan yang besar bagi yang melakukannya.Seperti memperbanyak keturunan, memperpanjang umur, mempererat kekerabatan dan yang terakhir memperlancar rezeki. Kesehatan keluarga menjadi bagian yang mendapat porsi perhatian yang besar bagi kedua keluarga. Dalam keluarga ustadz faktor modal sosial adalah karena beliau memiliki banyak murid yang berprofesi sebagai dokter. Hal ini disebabkan karena pekerjaan yang mendoronganya memiliki banyak relasi. Keluarga ustadz tidak memiliki dana emergensi, tidak menggikuti asuransi jiwa maupun asuransi kesehatan sebagai antsipasi jika ada salah satu anggota keluarga yang sakit. Berdasarkan penjelasaannya ketika beliau atau salah satu anggota keluarga ada yang sakit maka banyak yang membantu karena beliau memiliki banyak murid yang berprofesi sebagai dokter. Ini merupakan salah satu berkah menjadi seorang ustadz banyak yang simpatik terhadap beliau dan kelvarga. Sesungguhnya informan tidak mengharapkan diperlakukan seperti itu hanya saja mereka yang datang sendiri. Informan semakin yakin bahwa jika seseorang menjaga hatinya untuk Allah SWT maka Allah SWT akan menjaganya dari sisi yang tidak disangka.

Sedangkan keluarga dokter faktor modal sosial adalah profesinya sebagai dokter. Proteksi yang dilakukan bergantung pada fasilitas asuransi kesehatan yang diberikan rumah sakit tempat informan bekerja namun program tersebut memiliki batasan jumlah anggota kelvarga yang tertanggung. Hanya tiga anak yang tertanggung sedangkan dua anak lainya tidak ditanggung walaupun begitu informan memiliki banyak rekan sejawatnya ketika sakit biayanya dibebaskan hanya membayar biaya obat saja. Informan juga tidak menggunakan asuransi pendidikan dan berbagai produk asuransi lainnya karena menurut informan tidak ada alokasi dana untuk membayar premi.

\section{SIMPULAN}

Simpulan yang dapat diambil dari hasil analisi dan pembahasan yang telah dilakukan sebelumnya, adalah sebagai berikut:

1. Manajemen Pendapatan (Managing Income)

Prinsip ke Qowwaman suami itu ditopang ke shalihaan istri. Bahwa motivasi, niat, pemahaman agama dan latar belakang pekerjaan akan mempengaruhi seseorang dalam merencanakan dan memperoleh sumber pendapatan kelvarga. Kelvarga etnis arab melakukan perencanaan secara sederhana tidak secara terperinci dimana tujuan perencanaan dan pengelolaan keuangan keluarga berdasarkan tujuan jangka pendek.

2. Manajemen Kebutuhan (Managing Need)

Prinsip memprioritaskan pelunasan hutang sebelum dibelanjakan untuk kebutuhan primer. Pelunasan hutang menjadi prioritas utama dalam 
Bazher, et al/Jurnal Ekonomi Syariah Teori dan Terapan Vol. 4 No. 3 Maret 2017: 203-218; BAGAIMANA POLA PERENCANAAN DAN PENGELOLAAN KEUANGAN KELUARGA MUSLIM ETNIS ARAB YANG BERPROFESI USTADZ DAN DOKTER DI SURABAYA

pelaksanaan pembayarannya karena hutang merupakan kewajiban yang wajib dipenuhi sebelum menunaikan pembayaran zakat dan kebutuhan primer. Pendidikan merupakan pengeluaran yang paling besar karena informan berharap anak-anaknya memiliki masa depan yang baik sebab itu dipersiapkan dana pendidikan walaupun tidak secara khusus.

3. Manajemen Impian (Managing Dream) Memiliki prinsip fiqih prioritas yaitu mukadimah aham minal muhim yaitu selalu mendahulukan yang paling penting dari yang penting. Memperhatikan skala prioritas dan mendahulukan kebutuhan dari pada keinginan, memiliki keinginan namun keinginan tersebut dapat ditahan karena ada kebutuhan lain yang mendesak untuk dipenuhi.

4. Manajemen Surplus dan Defisit

(Managing Surplus Defisit)

Prinsip memprioritaskan investasi dari pada tabungan. Memiliki kesadaran yang cukup dalam menabung dan mengetahui bahwa tabungan itu penting sebagai salah satu sarana penyisihan vang yang harus dilakukan. Namun tidak memiliki tabungan secara khusus. Dalam mengatasi keadaan defisit keuangan kedua keluarga memiliki solusi yang berbeda .

5. Manajemen Ketidakpastian (Managing Contingencies)

Kedua keluarga tidak memiliki dana emergensi khusus namun secara tidak langsung keduanya memiliki faktor modal sosial yaitu hubungan kekerabatan yang muncul dari hobi bersilaturahmi.

Saran

Saran yang dapat penulis sampaikan pada penelitian ini adalah:

1. Kelvarga muslim hendaknya lebih memperhatikan lagi dalam merencanakan dan menggelola keuangan keluarga untuk jangka pendek maupun jangka panjang agar dapat terhindar dari konsumsi yang berlebih-lebihan (israf') walaupun dari kedua informan ini bisa terlihat bahwa mereka berusaha unntuk berhemat.

2. Peneliti selanjutnya diharap dapat meneliti tentang topik yang sama akan tetapi dengan kriteria informan yang lebih beragam, misalnya perbedaan lamanya usia menikah.

\section{DAFTAR PUSTAKA}

Adler H. Manurung dan Lutfi T Rizky. 2009. Successful Financial Planner a Complete Guide. Jakarta: PT Gramedia Widiasarana Indonesia.

Aulia. 2009. Perencanaan Keuangan Kelvarga Menciptakan Surplus Anggaran dalam Keuangan Keluarga Anda. Yogyakarta: Cakrawala.

Ghozie, Prita. 2013. Make It Happen! Jakarta: PT Gramedia Pustaka Utama.

Hidayat, Muhammad. 2010. an introduction to The Sharia Economic Pengantar Ekonomi Syariah. Jakarta: Zikrul Hakim.

Luqyan Tamanni, 2013. Sakinah Finance, Solusi Mudah Mengatur Keuangan Kelvarga Islami. Solo: Tinta Medina.

Paul B.Horton dan Chester L. Hunt. 2006. Sosiologi, Jilid I. Jakarta: Erlangga.

Pcim Mesir. 2015. Mengapa Suami Menjadi Pemimpin Istri. Artikel (online). (www.pcimmesir.com, diakses 19 maret 2016)

Pratiwi, R. D. 2010. Tingkat Kesadaran Masyarakat dalam Perencanaan Keuangan Keluarga Perspektif Ekonomi 
Islam. Skripsi tidak diterbitkan. Jakarta: Fakultas Syariah dan Hukum Universitas Islam Negri Syarif Hidayatullah.

Qardhawi, Yusuf. 1996. Fiqih Prioritas Sebuah Kajian Baru Berdasarkan AlQurán dan As-sunnah. Jakarta: Robbani Press. 1997. Norma Dan Etika Ekonomi Islam. Jakarta: Gema Insani Press. 1993. Halal dan Haram dalam Islam. Bangil: PT. Bina llmu.

Rini, M. 2014. Perencanaan Keuangan Bagi Buruh Migran Perempuan. Jakarta: UNIFEM

Rodhiyah. 2012. Manajemen Keuangan Keluarga Guna Menuju Keluarga Sejahtera. ejournal.undip.ac.id $\mathrm{Vol} 40$, No 1

Sanrego dan Taufik. 2016. Fiqih Tamkin (Fiqih Pemberdayaan) . Jakarta: Qisthi Pres.

Senduk, Safir. 2009. Mengelola Keuangan Kelvarga. Jakarta: PT Elex Media Komputindo.

Shihab, M. Quraish. 2009. Tafsir Al-Misbah volume 2. Jakarta: Lentera Hati.

Sugiyono, P. D. 2011. Metode Penelitian Kuantitatif Kualitatif dan $R$ \& $D$. Bandung: Alfabeta.

Suryaningrum, Senja .2008. Representatif Perempuan Keturunan Arab Dalam Pemakaian Kosmetik. Surakarta: Fakultas IImu Sosial Dan IImu Politik Universitas Sebelas Maret

Syahatah, Husein. 1998. Ekonomi Rumah Tangga Muslim. Jakarta: Gema Insani Press.

Syifa, L. 2011. Peran Perempuan Dalam Manajemen Keuangan Kelvarga Muda. Jakarta.

Van, D. B. 1989. Orang Arab di Nusantara. Jakarta: Komunitas Bambu.

Warsono. 2010. Prinsip-Prinsip dan Praktik Keuangan Pribadi. Volume 13 Nomor 2 Juli-Desember.

Widjajanto, J. 2014. Membangun Kesejahteraan Tujuan Perencanaan Kevangan artikel http:/joanneswidjajanto.blogspot.com. diakses pada 24 mei 2014

Wulandari, M. R. 2011. Perbedaan Minat Membuat Perencanaan Keuangan Syariah Berdasarkan Tingkat Pendidikan dan Status Marital Wanita Karir. Jakarta Syariah dan Hukum Universitas Islam
Negri Syarif Hidayatullah Jakarta: Skripsi tidak diterbitkan. 